\title{
FAKTOR-FAKTOR YANG MENENTUKAN AUDIT DELAY
}

\author{
Lidya Primta Surbakti dan Ayunita Ajengtiyas Saputri Mashuri \\ lydiaprimta@yahoo.co.id,ayunita.ajeng@gmail.com \\ Fakultas Ekonomi UPN "Veteran" Jakarta \\ Jl. R.S. Fatmawati Pondok Labu, Jakarta Selatan - 12450
}

\begin{abstract}
This study is performed to examine the effect of Auditor's Opinion, Solvency Size CPA Firm and profitability toward the probability to Audit Report Lag in Consumer Goods Industry in Indonesian Stock Exchange over period 2010-2012. The population of this research is 35 Consumer Goods Industry companies listed on the Indonesia Stock Exchange over period 2010-2012. The data is obtained based on corporate finance reporting that at publication. It is gained sample amount of 28 companies from 35 companies those are classified in Consumer Goods Industry in Indonesian Stock Exchange. The analysis technique used here is multiple linear regression and hypothesis test using $t$-statistic and $F$-statistic with level of significance $5 \%$. This research results that Auditor's Opinion, Size CPA Firm, Solvency and Gain-Loss are not significant effect to Audit Report Lag. We suggest for investors in Indonesian Stock Exchange that paying attention others factor that regards Audit Report Lag because with those information they can make the best decision for their investment.
\end{abstract}

Keywords: Audit Report Lag, Auditor's Opinion, Solvency, Size CPA Firm and Gain- loss

\section{PENDAHULUAN \\ LATAR BELAKANG}

Perkembangan pasar modal di Indonesia berdampak peningkatan permintaan akan audit laporan keuangan. (Kartika,2011). Setiap perusahaan yang go public diwajibkan untuk menyampaikan laporan keuangan yang sesuai dengan standar akuntansi keuangan dan telah diaudit oleh akuntan publik yang terdaftar di Badan Pengawas Pasar Modal.

Laporan keuangan merupakan media komunikasi antara manajemen dengan pihak di luar perusahaan. Kesesuaian informasi yang dikomunikasikan akan hilang jika terlambat disampaikan, oleh karena itu laporan keuangan haruslah disajikan tepat waktunya agar berguna bagi para pemakainya dalam pengambilan keputusan. Keinginan untuk menyajikan laporan keuangan tepat waktu sering dihadapkan dengan berbagai kendala. Salah satu kendala adalah adanya keharusan laporan keuangan untuk di audit oleh akuntan publik. Karena terbatasnya jumlah karyawan yang akan melakukan audit, banyaknya transaksi yang harus diaudit, kerumitan dari transaksi tersebut sehingga memerlukan waktu yang cukup panjang dalam proses pengauditan laporan keuangan tersebut. Jika terjadi penundaan dalam pelaporannya, menyebabkan informasi tidak lagi bermanfaat. Nilai kemanfaatan dari informasi yang terkandung dalam laporan keuangan akan bernilai, jika disajikan secara 
akurat dan tepat waktu, yakni tersedia pada saat yang dibutuhkan oleh para pengguna laporan keuangan.(Puspitasari,2012).

Nilai dari ketepatan waktu pelaporan keuangan merupakan faktor penting bagi kemanfaatan laporan keuangan tersebut.(Rachmawati,2008) Ketepatan waktu penyajian laporan keuangan (timeliness) dan lamanya penyelesaian audit (audit report lag) sebagai tolak ukur keberhasilan suatu perusahaan merupakan prasyarat utama bagi peningkatan kualitas perusahaan.(Puspitasari,2012).

Ketepatan waktu penyajian laporan keuangan auditan kepada masyarakat merupakan sinyal adanya informasi yang bermanfaat bagi para investor dan pengguna laporan keuangan lainnya untuk pembuatan keputusan.

Pada tahun 2013 terdapat fenomena yang menarik untuk dibahas. Berdasarkan catatan Bursa Efek Indonesia (BEI), sebanyak 7 emiten yang terlambat menyampaikan laporan keuangan auditan per 31 Desember 2012 hingga tanggal 28 Juni 2013 atau belum melakukan pembayaran denda atas keterlambatan penyampaian Laporan Keuangan tersebut. PT Bursa Efek Indonesia (BEI) melaporkan ketujuh emiten yang terkena suspensi itu adalah PT Bornero Lumbung Energi \& Metal Tbk (BORN), PT setady Safe Tbk (SAFE), PT Truba Alam Manunggal Engineering Tbk (TRUB) dan PT Zebra Nusantara Tbk. Sementara tiga perusahaan lainnya terkena perpanjang suspensi efek yaitu PT Davomas Abadi Tbk (DAVO), PT Berlian Laju Tanker Tbk (BLTA), dan PT Dayaindo Resources International Tbk
(KARK). Ketujuh emiten tersebut mendapatkan opini wajar namun dengan audit report lag yang semakin panjang. Merujuk pada Keputusan Ketua Badan Pengawas Pasar Modal Nomor : Kep-36/PM/2003 Nomor X.K.2 bahwa perusahaan yang terlambat menyampaikan laporan keuangan, perusahaan tersebut dikenakan denda sebesar Rp 150 juta.(http://bisnis.liputan6.com/read/62 6921/laporan-keuangan-2012-telat-7emiten-kena-suspensi. Senin, 16 September 2013 pukul 11:58 WIB).

Fenomena tersebut harus sesuai dengan peraturan yang berlaku bahwa perusahaan yang go public diwajibkan untuk menyampaikan laporan keuangan tahunan yang disertai dengan laporan akuntan dengan pendapat yang lazim kepada Badan Pengawas Pasar Modal (BAPEPAM) selambat-lambatnya pada akhir bulan ketiga setelah tanggal laporan keuangan tahunan. Hal ini dicantumkan dalam keputusan ketua Badan Pengawas Pasar Modal Nomor : Kep-36/PM/2003 nomor X.K2 tentang kewajiban penyampaian laporan keuangan berkala. Batas waktu penyampaian laporan keuangan tahunan perusahaan adalah 90 hari setelah tanggal berakhirnya tahun buku. Apabila peraturan ini dilanggar, maka Bapepam akan mengenakan sangsi kepada perusahaan yang tidak mematuhinya.

Penelitian ini dilakukan karena masih terdapat ketidak konsistenan dari hasil penelitian terdahulu dengan menggunakan proksi, dimensi waktu dan tempat yang berbeda.

Terdapat beberapa faktor yang mempengaruhi durasi waktu 
pengauditan laporan keuangan sehingga dilakukan penelitian dengan judul "FAKTOR-FAKTOR YANG MEMPENGARUHI AUDIT REPORT $L A G{ }^{\prime}$

\section{TINJUAN PUSTAKA}

\section{TELAAH LITERATUR DAN PENGEMBANGAN HIPOTESIS}

Penelitian terdahulu yang telah dilakukan oleh penelitian sebelumnya yang berkaitan dengan Opini Audit, Solvabilitas dan Ukuran KAP terhadap Audit Report Lag yang dapat digunakan sebagai bahan dalam penelitian ini.

Charslaw dan Kaplan (1991)

Dengan menggunakan sample 245 perusahaan firma di Selandia Baru tahun 1988. Variabel yang independen digunakan antara lain ukuran perusahaan, industri pendapatan, pos-pos luar biasa, pendapat audit, ukuran Kantor Akuntan Publik, akhir tahun perusahaan, kepemilikan perusahaan, dan proporsi hutang. Teknik pengambilan sample dengan cara random. Pengujian menggunakan model regresi sederhana dan regresi berganda. Hasil pengujian hipotesis menunjukkan bahwa industri, pendapatan, akhir tahun perusahaan, kepemilikan perusahaan dan proporsi hutang berpengaruh signifikan terhadap audit delay, sedangkan ukuran perusahaan, pos-pos luar biasa, pendapat audit, dan ukuran Kantor Akuntan Publik tidak berpengaruh secara signifikan terhadap audit delay. Keterbatasan penelitian ini adalah menambahkan variabel yang bersifat menjelaskan.
Ahmad dan Kamarudin (2003)

Sampel yang digunakan yaitu pada 100 perusahaan yang terdaftar di kuala lumpur stock exchange selama periode tahun 1996-2000. Pengujian menggunakan model regresi berganda. Variabel independen yang digunakan meliputi total asset, klasifikasi industri, pendapatan, pos-pos luar biasa, pendapat audit, ukuran Kantor Akuntan Publik, akhir tahun perusahaan, dan proporsi hutang. Kesimpulan dari penelitian tersebut menunjukkan bahwa variabel klasifikasi industri, pendapatan, pendatan audit, ukuran Kantor Akuntan Publik, akhir tahun perusahaan, dan proporsi hutang berpengaruh signifikan terhadap biasa signifikan terhadap audit delay, sedangkan total asset dan pos-pos luar biasa tidak berpengaruh signifikan terhadap audit delay.

Aryati dan Theresia (2005)

Sample yang digunakan adalah 50 perusahaan industri manufaktur yang terdaftar di Bursa Efek Jakarta dengan periode 2002-2004 yang telah melaporkan laporan keuangan berturut-turut. Alat uji yang digunakan dalam penelitian ini adalah regresi berganda. Faktorfaktor dalam penelitian ini adalah ukuran perusahaan, profitabilitas, keberadaan divisi internal audit dan ukuran KAP. Hasil penelitian ini adalah bahwa ukuran perusahaan berpengaruh signifikan terhadap audit delay. Sedangkan ukuran KAP, profitabilitas, dan keberadaan divisi internal auditor tidak berpengaruh terhadap audit delay.

Hendra (2005) 
Telah melakukan penelitian jumlah sample peneliti terdiri dari 178 perusahaan. Teknik pengambilan sample dipilih berdasarkan krteriakriteria tertentu. Faktor -faktor dalam penelitian ini adalah total asset, ukuran perusahaan, opini audit, besar nya KAP, proporsi hutang. Hasil penelitian ini adalah bahwa total asset, besarnya KAP dan proporsi hutang berpengaruh signifikan terhadap audit report lag. Sedangkan ukuran perusahaan dan opini audit tidak berpengaruh terhadap audit report lag. Keterbatasan dalam penelitian ini adalah bahwa objek penelitian hanya menggunakan perusahaan manufaktur yang terdaftar di Bursa Efek Indonesia tahun 2005-2009.

Petronila (2007)

Telah melakukan penelitian sample yang digunakan adalah 135 perusahaan non financial yang terdaftar di BEJ pada tahun 2003. Teknik pengambilan sample menggunakan metode convenience sampling. Pengujian dilakukan dengan model regresi linear berganda. Variabel independen yang diteliti yaitu skala/ukuran perusahaan, profitabilitas, pos-pos luar biasa, opini audit, dan umur perusahaan berpengaruh signifikan terhadap audit delay sedangkan ukuran KAP (Kantor Akuntan Publik) tidak berpengaruh signifikan terhadap audit delay.

\section{Rahmawati (2008)}

Telah melakukan penelitian dengan sample yang digunakan adalah perusahaan manufaktur yang terdaftar di Bursa Efek Indonesia tahun 2003-2005. Teknik pengambilan sample dengan cara purposive sampling. Pengujian ini menggunakan model regresi berganda. Variabel independen yang diteliti yaitu size perusahaan dan ukuran KAP (Kantor Akuntan Publik) berpengaruh signifikan terhadap audit delay sedangkan profitabilitas, solvabilitas, dan internal auditor tidak berpengaruh signifikan terhadap audit delay.

\section{Venny dan Ubaidillah (2008)}

Telah melakukan penelitian dengan sampel yang digunakan adalah 62 perusahaan yang terdaftar di Bursa Efek Jakarta hingga tahun 2005. Teknik pengambilan sampe dengan cara purposive sampling. Pengujian hipotesis digunakan metode analisis regresi berganda. Variabel independen yang digunakan yaitu opini auditor, profitabilitas, leverage, dan ukuran perusahaan. Dari hasil penelitian, opini auditor dan leverage berpengaruh signifikan terhadap audit delay.

\section{Kartika (2009)}

Telah melakukan penelitian dengan teknik pengambilan sample menggunakan cara purposive sampling. Dengan menggunakan sample pada perusahaan yang terdaftar di Bursa Efek Jakarta tahun 2001-2005. Hasil penelitian yang dilakukan faktor total asset,laba rugi operasi, mempunyai pengaruh yang negatif dan signifikan terhadap audit delay perusahaan. Faktor profit dan reputasi auditor tidak mempunyai pengaruh terhadap audit delay.

Shulthoni (2012)

Telah melakukan penelitian dengan teknik pengambilan sample menggunakan cara porposive 
sampling. Pengujian hipotesis digunakan metode analisis regresi berganda. Dengan menggunakan sample sebanyak 243 perusahaan selama 2 tahun berturut-turut yang terdaftar di Bursa Efek Indonesia tahun 2007-2008. Berdasarkan hasil penelitian determinan yang mempengaruhi audit delay adalah jenis industri, kinerja keuangan, dan Ukuran KAP. Hasil penelitian ini tidak berhasil menemukan pengaruh ukuran perusahaan, opini auditor, dan rasio utang terhadap audit delay. Keterbatasan dalam penelitian ini adalah hanya didasarkan pada sumber data sekunder di Bursa Efek Indonesia, sehingga variabel-variabel yang diteliti berasal dari data yang dipublikasikan.

\section{Teori Sinyal}

Teori sinyal menyatakan bahwa perusahaan yang memiliki kondisi keuangan yang baik maka perusahaan dengan sengaja akan memberikan sinyal pada publik. Teori sinyal (signaling theory) ini muncul dikarenakan terjadinya asimetri informasi, dimana manajer memiliki informasi yang berbeda (lebih baik) tentang prospek perusahaan dari pada investor, Brigham dan Houston (2006:38).

Untuk dapat mengatasi asimetri informasi tersebut maka perusahaan harus memberikan sinyal kepada publik mengenai kondisi perusahaan kepada stakeholder.Suatu sinyal dapat dikatakan efektif apabila sinyal tersebut dapat mempengaruhi pasar atau publik dalam mengambil suatu keputusan. Febrianty (2011) menyatakan manfaat utama teori ini adalah akurasi dan ketepatan waktu penyajian laporan keuangan ke publik merupakan sinyal dari perusahaan akan adanya informasi yang bermanfaat dalam kebutuhan dalam pembuatan keputusan dari investor.

Perusahaan yang memiliki kondisi keuangan yang baik akan memberikan sinyal publik dengan cari memperkecil audit report lag atau dapat menyampaikan laporan keuangan dengan segera. Namun apabila kondisi keuangan perusahaan tersebut buruk makan audit report lag akan menjadi panjang dan perusahaan telat dalam menyampaikan laporan keuangannya. Sehingga dapat disimpulkan bahwa sinyal yang diberikan perusahaan yang berkualitas baik maka akan di anggap sebagai berita baik sedangkan sinyal yang diberikan oleh perusahaan yang berkualitas buruk maka akan dianggap sebagai berita buruk.

\section{Audit Report Lag}

\section{Pengertian Audit Report Lag}

Ahmad dan Kamarudin (2003) menemukan bahwa audit report lag adalah "jumlah hari antara tanggal laporan keuangan dan tanggal laporan audit”.

Aryati dan Theresia (2005) menemukan bahwa Audit report Lag yaitu : rentang waktu penyelesaian pelaksanaan audit laporan keuangan tahunan, diukur berdasarkan lamanya hari yang dibutuhkan untuk memperoleh laporan auditor independen atas audit laporan keuangan tahunan perusahaan, sejak tanggal tutup buku 
perusahaan yaitu 31 desember sampai tanggal yang tertera pada laporan auditor independen.

Petronila (2007) menemukan bahwa Audit Report Lag adalah "jangka waktu antara tanggal tahun buku perusahaan berakhir sampai dengan tanggal laporan audit".

Dari beberapa definisi diatas dapat disimpulkan bahwa lamanya waktu penyelesaian audit terhitung mulai tanggal tutup buku sampai dengan tanggal penandatanganan oleh auditor pada laporan auditor independen.

\section{Pengembangan Hipotesis.}

Pengaruh Opini Auditor Terhadap Audit Report Lag

Dari pengertian opini audit yang telah dijelaskan menurut Agoes (2012:74) dan Kartika (2009) dalam landasan teori, dapat disimpulkan bahwa opini audit merupakan pendapat auditor terhadap kewajaran laporan keuangan yang diauditnya. Kewajaran atas laporan keuangan diperoleh setelah melakukan audit. Sebelum melakukan audit, dibutuhkan pemilihan sample. Semakin banyak sample yang harus diaudit, maka dibutukan waktu yang panjang untuk melaksanakan audit.

Opini audit yang terdapat dalam laporan keuangan menyatakan tentang kewajaran terhadap penyajian laporan keuangan apabila informasi yang terdapat dalam laporan keuangan belum disajikan secara wajar maka auditor perlu melakukan pemeriksaan secara mendalam dan hal ini menyebabkan auditor membutuhkan waktu yang lebih panjang untuk menyelesaikan proses audit. Penelitian yang dilakukan oleh Ahmad dan Kamarudin (2003) menyatakan bahwa perusahaan-perusahaan yang listing di Kuala Lumpur Stock Exchange yang tidak mendapatkan unqualified opinion (opini wajar tanpa pengecualian) akan memiliki jangka waktu pelaporan audit yang lebih lama. Hal ini terjadi karena proses pemberian pendapat qualified tersebut melibatkan negosiasi dengan klien, konsultasi dengan partner audit yang lebih senior.

Hal ini didukung oleh penelitian yang dilakukan Petronila (2007), Venny dan Ubaidillah (2008), dan Kartika (2009) yang menyatakan bahwa opini audit berpengaruh signifikan terhadap audit report lag.

Berdasarkan alasan yang telah dikemukakan tersebut, maka hipotesis yang dapat dikembangkan adalah :

H1 : Opini audit berpengaruh signifikan terhadap audit report lag.

\section{Pengaruh Solvabilitas terhadap Audit Report Lag}

Rasio ini adalah rasio yang digunakan untuk mengetahui perkembangan perusahaan dilihat dari segi kemampuan perusahaan untuk membayar kewajibannya. Dari penjelasan menurut Harahap (2011:306) dan Kasmir (2012:151) dalam landasan teori, dapat disimpulkan bahwa solvabilitas adalah untuk melihat seberapa besar aktiva perusahaan untuk membiayai hutang. Semakin besar hutang perusahaan yang dibiayai oleh modal, cenderung dikatakan kurang baik. Bagi kreditor, 
semakin besar rasio ini, akan tidak menguntungkan karena akan semakin besar risiko yang ditanggung atas kegagalan yang mungkin terjadi di perusahaan tersebut. Bagi auditor, perusahaan yang memiliki solvabilitas tinggi cenderung menyampaikan laporan tidak tepat waktu atau audit report lag semakin panjang. Sebaiknya jika perusahaan tidak memiliki solvabilitas rendah cenderung menyampaikan laporan keuangan tepat waktu atau audit report lag semakin pendek.

Menurut Venny dan Ubaidillah (2008), tingkat solvabilitas secara parsial mempunyai pengaruh terhadap audit report lag. Solvabilitas yang tinggi memberi arti bahwa perusahaan tersebut sangat tergantung pinjaman dari luar. Sebaliknya jika tingkat solvabilitas rendah maka permodalan tersebut lebih banyak didanai oleh pemilik perusahaan tersebut. Tingkat solvabilitas yang dihasilkan sebuah perusahaan dapat dijadikan informasi sekaligus sebagai sinyal kepada publik untuk mendapatkan gambaran mengenai kondisi perusahaan. Sinyal tersebut bisa berupa good news atau bad news. Dapat disimpulkan bahwa tingkat solvabilitas tinggi akan membuat audit report lag lebih panjang. Sebaliknya jika perusahaan memiliki solvabilitas rendah akan membuat audit report lag lebih pendek. Hal ini sejalan dengan penelitian Ahmad dan Kamarudin (2003).

Berdasarkan alasan yang diungkapkan tersebut, maka hipotesis yang dapat dikembangkang adalah : $\mathrm{H} 2$ : Solvabilitas berpengaruh signifikan terhadap audit report lag.

\section{Pengaruh Ukuran KAP terhadap Audit Report Lag}

Dari berberapa penjelasan menurut Agoes (2012:44) dan Rachmawati (2008) tentang Kantor Akuntan Publik dalam landasan teori, dapat disimpulkan bahwa Kantor Akuntan Publik (KAP) adalah suatu bentuk usaha yang memiliki izin sesuai dengan ketentuan perundangundangan, sebagai tempat bagi Akuntan Publik dalam memberikan jasa profesionalnya. Perusahaan yang go public biasanya menggunakan jasa akuntan publik karena perusahaan wajib menyampaikan laporan keuangan yang sudah diaudit oleh Kantor Akuntan Publik.

KAP yang besar merupakan KAP yang umumnya memiliki sumber daya yang lebih banyak dan lebih baik, ditunjang dengan kecanggihan dan keakuratan sistem yang digunakan karena biasanya KAP besar melakukan kerjasama internasional dan memiliki sumber dana yang besar, keadaan ini akan membantu dalam melakukan proses audit sehingga dapat menimbulkan jangka waktu audit dan hasil audit dapat disampaikan tepat waktu. Penelitian ini dilakukan di Malaysia oleh Ahmad dan Kamarudin (2003).

Menurut Petronila (2007) pada umumnya Kantor Akuntan Publik (KAP) besar (KAP yang bekerja sama dengan dengan KAP Internasional) pada umumnya memiliki sumber daya yang lebih banyak dan lebih baik, ditunjang dengan kecanggihan dan keakuratan sistem yang digunakan karena biasanya KAP besar melakukan kerjasama Internasional 
dan memiliki sumber dana yang besar. Keadaan ini akan membantu dalam melakukan proses audit sehingga dapat meminimalkan jangka waktu audit dan hasil audit dapat disampaikan tepat waktu dibanding KAP kecil. Hal ini didukung oleh oleh penelitian yang dilakukan Hendra (2005), Rachmawati (2008), Shulthoni (2012) yang menyatakan bahwa ukuran KAP berpengaruh signifikan terhadap audit report lag. Berdasarkan alasan yang telah dikemukakan tersebut, maka hipotesis yang dapat dikembangkan adalah :

H3 : Ukuran KAP berpengaruh signifikan terhadap audit report lag.

Pengaruh laba/ rugi tahun berjalan terhadap Audit Report Lag

Perusahaan dengan laba yang besar tidak ada alasan untuk menunda penerbitan laporan keuangan auditan karena ini merupakan berita baik yaitu prestasi yang dicapai cukup menggembirakan. Sebaliknya, perusahaan yang menderita kerugian akan berusaha memperlambat penerbitan laporan keuangan auditan (Ashton et. al, 1984 dalam penelitian Soegeng Soetedjo, 2006). Auditor akan berhati-hati selama proses audit dalam merespon kerugian perusahaan apakah kerugian tersebut disebabkan oleh kegagalan finansial atau kecurangan manajemen. Jadi, semakin laba suatu operasi perusahaan, maka audit delaynya semakin pendek. Kartika (2009) Berdasarkan uraian teoritis diatas maka hipotesis alternatif yang disusun sebagai berikut:

H4 : laba/rugi tahun berjalan berpengaruh signifikan terhadap audit report lag.

\section{METODE PENELITIAN}

\section{Populasi dan Sampel Penelitian}

Populasi yang digunakan sebagai objek dalam penelitian ini adalah perusahaan manufaktur yang menerbitkan laporan keuangan tahunan (annually financial report) yang diaudit dan dipublikasikan di Bursa Efek Indonesia (BEI) untuk periode tahun 2010 sampai dengan tahun 2012 secara berturut-turut.

Sampel merupakan suatu sub kelompok dari populasi yang dipilih dalam penelitian.. Sampel yang digunakan adalah perusahan dalam industri barang konsumsi yang terdaftar di BEI

\section{Metode Penentuan Sample}

Penentuan sampel yang digunakan dalam penelitian ini adalah dengan menggunakan metode purposive sampling, yaitu metode penentuan sampel dengan berdasarkan pada kriteria tertentu. Adapun kriteria pemilihan sampel penelitian adalah sebagai berikut:

1. Perusahaan konsumsi manufaktur yang terdaftar di Bursa Efek Indonesia (BEI) berturut-turut sejak tahun 2010-2012.

2. Perusahaan melaporkan laporan keuangan tahunan dalam satuan mata uang Rupiah.

3. Perusahaan yang menyajikan laporan auditor independen.

4. Perusahaan yang melaporkan laporan keuangannya yang berakhir tahun buku per 31 Desember.

\section{Jenis dari Sumber Data Jenis Penelitan}


Data yang digunakan dalam penelitian ini adalah data sekunder, yaitu data yang diperoleh secara tidak langsung dari sumber utama (perusahaan) yang dijadikan objek penelitian. Data tersebut berupa laporan keuangan tahunan auditan perusahaan publik yang tergolong dalam industri manufaktur selama kurun waktu 3 tahun dan data lain yang berhubungan dengan masalah penelitian.

\section{Sumber Data}

Seluruh data penelitian bersumber dari laporan keuangan tahunan auditan perusahaan publik dalam industri barang konsumsi untuk periode tahun 2010-2012 yang dipublikasikan secara lengkap di Bursa Efek Indonesia (BEI). Sumber data diperoleh dari akses langsung dari website www.idx.co.id

\section{Operasionalisasi Variabel}

Definisi operasional yang digunakan dalam penelitian ini adalah sebagai berikut:

1. Variabel Dependen (Y)

Variabel Dependen dalam penelitian ini adalah Audit Report Lag.

2. Variabel Independen (X)

Variabel independen adalah variabel yang mempengaruhi variabel terikat. Variabel independen yang digunakan dalam penelitian ini adalah:

a. Opini Audit $\left(\mathrm{X}_{1}\right)$

Diukur dengan dummy yaitu untuk opini wajar tanpa pengecualian (unqualified opinion) diberi kode dummy 1 dan untuk opini wajar dengan pengecualian (qualified opinion) diberi kode dummy 0

b. Solvabilitas $\left(\mathrm{X}_{2}\right)$

Solvabilitas adalah seberapa jauh perusahaan dibiayai oleh utang atau pihak luar dengan kemampuan perusahaan yang digambarkan oleh ekuitas. (Harahap 2011:306).

c. Ukuran $\mathrm{KAP}\left(\mathrm{X}_{3}\right)$

Diukur dengan menggunakan dummy dengan mengelompokkan auditorauditor yang berasal dari KAP yang bermitra dengan kelompok empat besar (the big four). Kelompok 4 besar diberi kode 1, sedangkan untuk KAP selain yang bermitra dengan kelompok 4 besar diberi kode 0

d. Laba/ rugi periode berjalan

Diukur dengan dummy yaitu untuk perusahaan yang mengalami laba diberi kode dummy 1 dan yang mengalami rugi diberi kode dummy 0. Kartika (2009).

\section{Teknik Analisis Data}

Dalam melakukan analisis dan uji hipotesis, prosedur yang dilakukan dibantu dengan menggunakan program komputer yaitu IBM SPSS Statistic versi 20 dan Microsoft excel 2010. Dalam penelitian ini Metode analisis yang digunakan adalah uji statistik deskriptif dan uji hipotesis dengan menggunakan regresi linier berganda. 


\section{HASIL DAN PEMBAHASAN}

Descriptive Statistics

\begin{tabular}{|l|rr|r|r|r|r|}
\hline & \multicolumn{1}{|c|}{$\mathrm{N}$} & \multicolumn{1}{c|}{ Mean } & Std. Deviation & \multicolumn{1}{c|}{ Minimum } & \multicolumn{1}{c|}{ Maximum } \\
\hline ARL & 84 & 72.8095 & 12.47211 & 33.00 & 102.00 \\
Solva & & & 139.8412 & 352.51632 & 10.41 & 2448.30 \\
\hline
\end{tabular}

Berdasarkan hasil statistik lamanya audit report lag tidak deskriptif dapat diketahui bahwa jumlah sampel yang digunakan dalam penelitian ini adalah 84 . Tabel diatas menunjukkan rata-rata audit report lag yang terjadi pada perusahaan industri barang konsumsi yang terdaftar di Bursa Efek Indonesia pada tahun 2011 sampai dengan tahun 2013 adalah 72 hari. Artinya secara rata-rata

melewati batas waktu penyampaian laporan keuangan yaitu kurang dari 90 hari. Nilai minimum audit report Lag sebesar 33 hari sedangkan nilai maksimum audit report lag sebesar 102 hari. Dan solvabilitas rata - rata 139 persen dengan minimum solvabilitas 10,41 persen sedangkan maximum sebesar 2448 persen.

\section{Opini}

\begin{tabular}{|rl|r|r|r|r|}
\hline & & Frequency & Percent & Valid Percent & $\begin{array}{c}\text { Cumulative } \\
\text { Percent }\end{array}$ \\
\hline \multirow{2}{*}{ Valid } & .00 & 11 & 13.1 & 13.1 & 13.1 \\
& 1.00 & 73 & 86.9 & 86.9 & 100.0 \\
& Total & 84 & 100.0 & 100.0 & \\
\hline
\end{tabular}

Dari tabel diatas dapat dilihat 73 laporan keuangan mendapat opini mendapat opini audit non unqualified audit unqualified dan 11 laporan

dari 84 laporan keuangan.

KAP

\begin{tabular}{|ll|r|r|r|r|}
\hline & & Frequency & Percent & Valid Percent & $\begin{array}{c}\text { Cumulative } \\
\text { Percent }\end{array}$ \\
\hline \multirow{2}{*}{ Valid } & .00 & 39 & 46.4 & 46.4 & 46.4 \\
& 1.00 & 45 & 53.6 & 53.6 & 100.0 \\
& Total & 84 & 100.0 & 100.0 & \\
\hline
\end{tabular}

Dari tabel diatas dapat dilihat 45 laporan keuangan diaudit KAP The big four dan 39 laporan keuangan yang diaudit non the big Four.

labarugi

\begin{tabular}{|rl|r|r|r|r|}
\hline & & Frequency & Percent & Valid Percent & $\begin{array}{c}\text { Cumulative } \\
\text { Percent }\end{array}$ \\
\hline \multirow{2}{*}{ Valid } & .00 & 4 & 4.8 & 4.8 & 4.8 \\
& 1.00 & 80 & 95.2 & 95.2 & 100.0 \\
& Total & 84 & 100.0 & 100.0 & \\
\hline
\end{tabular}


Dari tabel diatas dapat dilihat 80 laporan keuangan yang dapat laba dan 4 laporan keuangan yang mendapat rugi.

\section{Uji asumsi klasik}

Dari uji statistik yaitu uji Kolmogrov-Smirnov (K-S) terdapat 0,094 . Jika nilai signifikansi $>0,05$ maka data tersebut berdistribusi normal. Dengan demikian 0,094> 0,05 maka data terdistribusi secara normal.

Tests of Normality

\begin{tabular}{|l|r|r|c|}
\hline \multirow{2}{*}{} & \multicolumn{4}{|c|}{ Kolmogorov-Smirnov ${ }^{\mathrm{a}}$} \\
\cline { 2 - 4 } & Statistic & \multicolumn{1}{c|}{$\mathrm{df}$} & \multicolumn{1}{c|}{ Sig. } \\
\hline ARL & .089 & 84 & .094 \\
\hline
\end{tabular}

a. Lilliefors Significance Correction

\section{Uji Autokorelasi}

Dari tabel diketahui bahwa nilai Durbin Watson (DW) diperoleh sebesar 1.725 angka Dw berada diantara -2 dan +2 Hal ini menunjukkan bahwa persamaan regresi dalam penelitian ini tidak terjadi autokorelasi.

Model Summary ${ }^{\mathrm{b}}$

\begin{tabular}{|l|r|}
\hline Model & Durbin-Watson \\
\hline 1 & 1.725 \\
\hline
\end{tabular}

a. Predictors: (Constant), labarugi, Opini, Solvabilitas, KAP b. Dependent Variable: ARL

\section{Uji Heteroskedastisitas}

Hasil uji heteroskedastisitas pada gambar grafik tersebut tidak ada pola yang jelas, serta titik-titik menyebar di atas dan di bawah angka 0 pada sumbu Y secara acak, maka tidak terjadi heteroskedastisitas atau model homoskedastisitas.

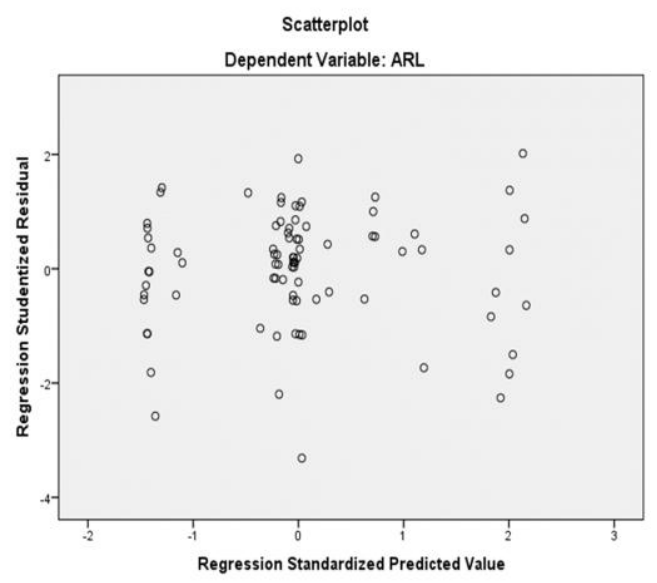

\section{Uji Multikoliniaritas}

Multikolinieritas digunakan untuk menguji apakah model regresi ditemukan adanya korelasi antar variabel bebas (independen). Model regresi yang baik seharusnya tidak terjadi korelasi di antara variabel independen.

Pendeteksiannya dilakukan dengan menggunakan tolerance value dan VIF (variance inflation factor). Jika nilai tolerance value $>0,10$ dan $\mathrm{VIF}<10$ maka tidak terjadi multikolinearitas . Dan dari tabel diatas tidak terdapat multikolinearitas.

Coefficients $^{\mathrm{a}}$

\begin{tabular}{|rl|r|r|}
\hline Model & \multicolumn{2}{|c|}{ Collinearity Statistics } \\
\cline { 3 - 4 } & & Tolerance & \multicolumn{1}{c|}{ VIF } \\
\hline \multirow{3}{*}{1} & (Constant) & & \\
& Opini & .967 & 1.034 \\
& Solvabilitas & .845 & 1.184 \\
& KAP & .812 & 1.232 \\
& labarugi & .913 & 1.095 \\
\hline
\end{tabular}

a. Dependent Variable: ARL 
Menguji Koefisien Determinasi

Model Summary ${ }^{b}$

\begin{tabular}{|l|c|c|c|}
\hline $\begin{array}{l}\text { Mod } \\
\text { el }\end{array}$ & $R$ & $\begin{array}{c}R \\
\text { Square }\end{array}$ & $\begin{array}{c}\text { Adjusted } R \\
\text { Square }\end{array}$ \\
\hline 1 & $.295^{\mathrm{a}}$ & .087 & .041 \\
\hline
\end{tabular}

a. Predictors: (Constant), labarugi, Opini, Solvabilitas, KAP

b. Dependent Variable: ARL

Tabel menunjukkan bahwa

Adjusted $R$ Square adalah sebesar
0,041. Hal ini menunjukkan bahwa presentase sumbangan pengaruh opini audit, solvabilitas, dan ukuran KAP terhadap audit report lag adalah 4,1 $\%$, sedangkan sisanya sebesar 95,9\% dipengaruhi oleh variabel lain yang lebih dominan diluar variabel yang diteliti.

\section{Uji Signifikan Simultan (Uji Statistik F)}

ANOVA $^{a}$

\begin{tabular}{|rl|c|r|r|r|r|}
\hline Model & \multicolumn{1}{c|}{$\begin{array}{c}\text { Sum of } \\
\text { Squares }\end{array}$} & $\mathrm{df}$ & Mean Square & $\mathrm{F}$ & Sig. \\
\hline \multirow{3}{*}{1} & Regression & 1122.269 & 4 & 280.567 & 1.880 & $.122^{\mathrm{D}}$ \\
& Residual & 11788.683 & 79 & 149.224 & & \\
& Total & 12910.952 & 83 & & & \\
\hline
\end{tabular}

a. Dependent Variable: ARL

b. Predictors: (Constant), labarugi, Opini, Solvabilitas, KAP

Dari uji ANOVA (Analysis of Varians) atau uji F tingkat signifikansi sebesar $0,122>0.05$. Hal ini berarti bahwa Ho diterima dan Ha ditolak sehingga dapat disimpulkan bahwa opini audit, solvabilitas, ukuran KAP dan laba -rugi secara simultan mempunyai pengaruh tidak signifikan terhadap audit report lag.

\section{Pengujian Parsial}

Dari tabel diatas dapat diketahui mempunyai nilai signifikansi sebesar $0,065>0,05$. Hal untuk variabel opini audit berarti bahwa Ho diterima dan Ha ditolak, sehingga dapat disimpulkan opini audit berpengaruh tidak signifikan terhadap audit report lag.

Pada tabel dapat diketahui diketahui bahwa solvabilitas mempunyai nilai signifikan sebesar $0,206>0,05$. Hal ini berarti bahwa Ho diterima dan Ha ditolak, sehingga dapat disimpulkan solvabilitas berpengaruh tidak signifikan terhadap audit report lag.

Pada tabel dapat diketahui bahwa ukuran KAP mempunyai nilai signifikansi sebesar 0,098>0,05. Hal ini berarti bahwa Ho ditolak dan $\mathrm{Ha}$ diterima, sehingga dapat disimpulkan ukuran KAP berpengaruh tidak signifikan terhadap audi report lag.

Pada tabel dapat diketahui bahwa laba - rugi mempunyai nilai signifikansi sebesar 0,064>0,05. Hal ini berarti bahwa Ho ditolak dan $\mathrm{Ha}$ diterima, sehingga dapat disimpulkan ukuran KAP berpengaruh tidak signifikan terhadap audi report lag. 
Coefficients $^{\mathrm{a}}$

\begin{tabular}{|c|c|c|c|c|c|c|}
\hline \multirow{2}{*}{\multicolumn{2}{|c|}{ Model }} & \multicolumn{2}{|c|}{ Unstandardized Coefficients } & Standardized & \multirow[t]{2}{*}{$\mathrm{t}$} & \multirow[t]{2}{*}{ Sig. } \\
\hline & & $B$ & Std. Error & Beta & & \\
\hline \multirow{5}{*}{1} & (Constant) & 92.632 & 8.045 & & 11.514 & .000 \\
\hline & Opini & -7.518 & 4.018 & -.205 & -1.871 & .065 \\
\hline & Solvabilitas & .195 & .153 & .149 & 1.274 & .206 \\
\hline & KAP & -4.970 & 2.966 & -.200 & -1.676 & .098 \\
\hline & labarugi & -12.291 & 6.548 & -.211 & -1.877 & .064 \\
\hline
\end{tabular}

a. Dependent Variable: ARL

\section{DISKUSI}

Berdasarkan penelitian yang telah dilakukan, mengenai pengaruh opini audit, solvabilitas ukuran KAP dan laba -rugi pada perusahaan industri sektor barang konsumsi yang terdaftar di Bursa Efek Indonesia, dengan sampel sebanyak 84 perusahaan pada tahun 2010-2012. Dari uji ANOVA atau uji $F$, menunjukkan bahwa nilai signifikansi sebesar $0,122<0,05$. Maka hipotesisnya penelitian ini diterima. Hal ini menunjukkan bahwa opini audit, solvabilitas, ukuran KAP dan laba -rugi secara bersama-sama berpengaruh tidak signifikan terhadap audit report lag.

Variabel opini audit menunjukkan nilai signifikansi 0,065 lebih besar dari 0,05 , sehingga dapat disimpulkan bahwa opini audit berpengaruh tidak signifikan terhadap audit report lag.

Perusahaan sampel yang mendapat unqualified opinion membutuhkan waktu lebih pendek untuk menyelesaikan proses audit. Walaupun demikian tidak dipungkiri bahwa perusahaan yang mendapat Unqulified opinion justru memerlukan audit report lag yang semakin panjang. Hal ini menunjukkan bahwa perusahaan yang memperoleh opini wajar tanpa pengecualian (unqualified opinion) tidak menyelesaikan audit lebih cepat dibandingkan perusahaan yang memperoleh selain unqualified opinion. Hal ini dikarena kan jenis pendapat audit merupakan good news atau bad news. Hasil penelitian ini didukung oleh penelitian yang dilakukan hendra (2005) dan shulthoni (2012) yang menyatakan bahwa opini audit berpengaruh tidak signifikan terhadap audit report lag.

Variabel solvabilitas diukur dengan debt to equity ratio menunjukkan nilai signifikansi 0,206 lebih besar dari 0,05 sehingga dapat disimpulkan solvabilitas berpengaruh tidak signifikan terhadap audit report lag. Solvabilitas yang tinggi memberi arti bahwa perusahaan tersebut sangat tergantung pinjaman dari luar. Sebaliknya jika tingkat solvabilitas rendah maka permodalan tersebut lebih banyak didanai oleh pemilik perusahaan tersebut.

Dapat disimpulkan bahwa tingkat solvabilitas tinggi akan membuat audit report lag lebih panjang. Sebaliknya jika perusahaan memiliki solvabilitas rendah akan membuat audit report lag lebih pendek. Tetapi dari hasil solvabilitas 
berpengaruh tidak signifikan terhadap audit report lag hal ini disebabkan hutang yang terdapat di perusahaan tidak mengeluarkan banyak waktu yang signifikan oleh auditor dalam mengaudit.

Hasil penelitian ini mendukung penelitian Rahmawati

(2008) berpengaruh tidak signifikan terhadap audit report lag.

Variabel ukuran KAP menunjukan nilai signifikansi 0,098 lebih besar dari 0,05 sehingga dapat disimpulkan ukuran KAP berpengaruh tidak signifikan terhadap audit report lag. Perusahaan yang go public biasanya menggunakan jasa akuntan publik karena perusahaan wajib menyampaikan laporan keuangan yang sudah diaudit oleh Kantor Akuntan Publik. KAP yang besar merupakan KAP yang umumnya memiliki sumber daya yang lebih banyak dan lebih baik, ditunjang dengan kecanggihan dan keakuratan sistem yang digunakan karena biasanya KAP besar melakukan kerjasama internasional dan memiliki sumber dana yang besar, keadaan ini akan membantu dalam melakukan proses audit sehingga dapat menimbulkan jangka waktu audit dan hasil audit dapat disampaikan tepat waktu. KAP yang berafiliasi dengan big four maupun non big four telah menggunakan prosedur standar audit yang berlaku, sehngga hasil dari audit tidak jauh berbeda yang mengakibatkan ketepatan waktu dalam mengaudit laporan keuangan. Hasil penelitian ini mendukung penelitian Aryati dan theresia (2005), Petronila (2007) yang menyatakan bahwa ukuran KAP berpengaruh tidak signifikan terhadap audit report lag.

Variabel laba- rugi menunjukan nilai signifikansi 0,064 lebih besar dari 0,05 sehingga dapat disimpulkan laba- rugi berpengaruh tidak signifikan terhadap audit report lag. Perusahaan yang mendapat laba atau rugi tidak mempengaruhi auditor dalam lamanya mengaudit laporan keuangan karena auditor sudah memiliki sistem dan sumber daya manusia yang baik .

\section{SIMPULAN}

Berdasarkan hasil penelitian dan pembahasan yang telah diuraikan, maka dapat diambil kesimpulan sebagai berikut:

1. Hasil pengujian secara simultan menunjukan bahwa variabel independen, yaitu Opini Audit, Solvabilitas dan Ukuran KAP secara bersama-sama berpengaruh tidak signifikan terhadap Audit Report Lag.

2. Hasil pengujian secara parsial menunjukan bahwa:

a. Opini Audit secara parsial berpengaruh tidak signifikan terhadap Audit Report Lag.

b. Solvabilitas secara parsial berpengaruh tidak signifikan terhadap Audit Report Lag.

c. Ukuran KAP secara parsial berpengaruh tidak signifikan terhadap Audit Report Lag.

d. Laba- rugi secara parsial berpengaruh tidak signifikan terhadap Audit Report Lag. 
3. Pengujian koefisien determinasi $\left(\mathrm{R}^{2}\right)$ dari Adjusted $\mathrm{R}$ Square menunjukkan bahwa Audit Report Lag hanya mampu dijelaskan sebesar 4,1\% oleh variabel Opini Audit, Solvabilitas, Ukuran KAP dan Laba - rugi. Sedangkan sisanya sebesar 95,9\% dijelaskan oleh faktor-faktor lain diluar variabel-variabel yang diteliti.

\section{DAFTAR PUSTAKA}

Agoes Sukrisno. (2012). Auditing Petunjuk Praktis Pemeriksaan Akuntan oleh Akuntan Publik, edisi 4. Jakarta: Salemba Empat. Ahmad dan Kamarudin. (2003). Audit Delay and The Timeliness of Corporate Reporting

Malaysian Evidence. Malaysia: MARA University o Technology. Aryati, Titik dan Maria Theresia. (2005). Faktor-Faktor yang Mempengaruhi Audit Delay dan Timeliness. Media Riset Akuntansi,Auditing dan Informasi.Vol.5, No.

3,Desember, hal 271-287.

Badan Pengawas Pasar Modal Nomor : Kep-36/PM/2003 nomor X.K2 tentang Kewajiban Penyampaian Laporan Keuangan Berkala.

Badan Pengawas Pasar Modal No.KEP 80/PM/1996 mengenai Penyampaian Laporan Keuangan.

Bisnis Liputan 6 : Kasus Laporan Keuangan 2012 Telat 7 Emiten Kena Suspensi diakses 16 September

2013http://bisnis.liputan6.com/r ead/626921/laporan-keuangan- 2012-telat-7-emiten-kena-

suspensi

Caslaw dan Kaplan (1991). An Examination of Audit Delay : Further Evidence from New Zealand. Accounting and Bussiness Research. Volume 22, No. 58: 21-32.

Elders, Radal, Beasley, Mark, and Arens. (2008). Auditing dan Jasa Assurance, Edisi Kedua belas, Jilid 1. Jakarta: Erlangga.

Elder, Randal, Beasley, Mark, and Arens. (2011). Auditing dan Jasa Assurance, edisi dua belas, jilid 1. Jakarta: Erlangga.

Harahap, Sofyan Syafri. (2011). Analisis Kritis atas Laporan Keuangan. Jakarta: Raja Grafindo Persada.

Houston dan Brigham. (2007), Dasardasar Manajemen Keuangan, Jakarta : Salemba Empat.

Institut Akuntan Publik Indonesia. (2011). Standar Profesional Akuntan Publik, Per 31 Januari 2011. Jakarta : Salemba Empat.

Hendra (2005) Pengaruh Total Asset, Ukuran Perusahaan, Laba atau Rugi Tahun Berjalan, Opini Audit, Besarnya KAP dan Proporsi Hutang Terhadap Audit Report Lag Pada Perusahaan Industri Manufaktur Yang Terdaftar di BEI.Jurnal Akuntansi. Tahun 2005.

Kartika, Andi. (2009). Faktor-Faktor Yang Mempengaruhi Audit Delay Di Indonesia (Studi Empiris Pada PerusahaanPerusahaan LQ 45 Yang Terdaftar Di Bursa Efek Jakarta). Jurnal Bisnis dan 
Ekonomi. Vol. 16, No. 1, Maret 2009: 1-17.

Kasmir. (2012). Analisis Laporan

Keuangan. Jakarta: Rajawali

Pers.

Petronila, Thio Anastasia. (2007). Analisa Skala Perusahaan, Profitabilitas, Opini Audit, dan Umur Perusahaan Atas Audit Delay. Akuntabilitas. Volume 6, No.2; 144-156.

Rachmawati, Sistya. (2008). Pengaruh Faktor Internal dan Eksternal Perusahaan terhadap Audit Delay dan Timeliness. Jurnal Akuntansi dan Keuangan.Vol. 10,No. 1, Mei, hal 347-356.

Santoso, Singgih (2012). Aplikasi SPSS pada Statistik Parametik. Jakarta: PT Elex Media Komputindo.

Sitanggang (2012), Manajemen Keuangan Perusahaan. Jakarta: Mitra Wacana Media.

Shulthoni, Mochammad. Determinan Audit Delay Dan Pengaruhnya Terhadap Reaksi Investor (Studi Empiris pada Perusahaan yang Listing di BEI Tahun 20072008). Jurnal Akuntansi dan Ekonomi Bisnis. Vol. 1, No. 1, Tahun 2012.

Sulistyanto, Sri (2008), Manajemen Laba Teori dan Model Empiris. Jakarta PT Grasindo.

Venny dan Ubaidillah. (2008). Audit Delay pada Perusahaan Manufaktur Studi Kasus: Bapepam Tahun 2005. Akuntanbilitas: Jurnal Penelitian dan Pengembangan Akuntansi. Volume 2,No.2. Juli. 